\title{
真空遮断器の最近の動向
}

斉 藤仁*1

\section{Recent Trend of Vacuum Circuit Breakers}

\author{
Hitoshi SAITO*1
}

\begin{abstract}
Medium Voltage Switchgear Development Department Japan AE Power Systems Corporation,
\end{abstract} 585 Shimonakamizo Higashimakado Numazu-City, Shizuoka 4100865 Japan

(Received February 3, 2009, Accepted May 9, 2009)

\begin{abstract}
The recent trend in the development and the application of Vacuum Circuit Breakers (VCBs) as an environmental friendly equipment for electric power transmission and distribution is described. Using VCB's for circuit breakers and switchgear and extending the range of application of VCB's lead to reduce the usage of $\mathrm{SF}_{6}$ gas, whose global warming potential is approximately 23900 times that of $\mathrm{CO}_{2}$. The rated voltages and interruption currents of VCB's have increased up to $145 \mathrm{kV} / 40 \mathrm{kA}$ for single break due to the improvement of the electrode materials and structures. Also, $\mathrm{SF}_{6}$ gas free switchgear up to $84 \mathrm{kV}$ using compressed dry air insulation systems have been developed.
\end{abstract}

\section{1. はじめに}

真空技術の産業応用製品のひとつに真空遮断器（VCB; Vacuum Circuit Breaker) がある. VCB は電力用遮断器の ひとつで, 真空中の優れた電流遮断（アーク消弧）能力を利 用している. 電力用遮断器の消弧媒体には, 大電流を遮断す る能力の他に, 高電圧に耐える絶縁性能も兼ね備えているこ とが望まれる、これらの要素を満たすものとして, 真空のほ かに, 空気, 油, 六弗化硫黄 $\left(\mathrm{SF}_{6}\right)$ ガスを消弧媒体に用い た遮断器があるが, 小型化, 高電圧化, 大容量化, メンテナ ンスの容易さなどの面から, 現在は $\mathrm{SF}_{6}$ ガス遮断器と真空 遮断器が主流になっている.

ここで, 電力機器に使われる $\mathrm{SF}_{6}$ ガスについて説明する. $\mathrm{SF}_{6}$ ガスは, 地球温暖化係数が $\mathrm{CO}_{2}$ の23900倍と大きく, 地 球温暖化ガスのひとつに指定されている. $\mathrm{SF}_{6}$ は安定性が高 く, 長期間大気中に分解されずに残留することも温暖化係数 が大きい要因のひとつである. 代替ガスの研究が盛んに行わ れたが, 絶縁性能, 消弧性能, 沸点, 毒性などで $\mathrm{SF}_{6}$ に優 るガスは見出されていない。 電力機器では $\mathrm{SF}_{6}$ ガスをタン ク内に封じ込めて使用するため, シール面からの漏れ, 製 造, 点検, 試験, 廃棄時のガス回収を徹底することで $\mathrm{SF}_{6}$ ガスの大気中への排出を減らすことが可能である. 電気事業 連合会では，1998年 4 月に「電気事業に抢ける $\mathrm{SF}_{6}$ 排出抑 制に関する自主行動計画」を策定し, いち早く $\mathrm{SF}_{6}$ ガス排 出の削減に取り組んだ. 機器点検時の排出割合を 2005 年に は $3 \%$ 程度まで, 機器廃棄時の排出割合を 2005 年には $1 \%$ 程 度まで抑制するという目標をすでに達成している。これに は, 機器メーカー, 電力会社などのユーザー, ガス取り扱い 業者などの協力体制のもと, ガス回収機の導入などが進めら れた成果である。

$\mathrm{SF}_{6}$ ガスを利用した電力機器にはガス絶縁変圧器 (GIT; Gas Insulated Transformer), ガス遮断器 (GCB; Gas Cir-

\footnotetext{
*1 秼日本 $\mathrm{AE}$ パワーシステムズ

テ410-0865 静岡県沼津市東門間字下中溝585
}

cuit Breaker)，ガス絶縁開閉装置（GIS; Gas Insulated Switchgear), などがある. これらの機器は, ガスの管理を強化 して使用を続けていくことが基本であるが, 温暖化防止の機 運により $\mathrm{SF}_{6}$ ガスを使用しないほうが経済的なメリットが 生じる場合もあり, 技術的に可能な範囲で脱 $\mathrm{SF}_{6}$ ガスの動 きが進んでいる.

GIT は $\mathrm{SF}_{6}$ ガスの絶縁性能とともに分子量146に起因する 冷却性能の高さ, さらには不燃性という特徵を生かして地下 変電所への適用が拡大している.この分野では鉱油と比べ難 燃性で, $\mathrm{SF}_{6}$ ガスより絶縁冷却性能が優れるシリコーン液入 りの防災・環境対応型変圧器が製品化されている.

GCB は $\mathrm{SF}_{6}$ ガスの優れたアーク消弧能力を, また, GIS は空気の約 3 倍に相当する $\mathrm{SF}_{6}$ ガスの高い絶縁性能を利用 したものである.これらの機器については中電圧以下の機器 から VCB の適用拡大による脱 $\mathrm{SF}_{6}$ ガスへの取り組みが行わ れている. 次章では, 実際に機器のどの部分に $\mathrm{SF}_{6}$ ガスや 真空が使われているか解説する.

\section{2. 遮断器 · ガス絶縁開閉装置の構成}

Fig. 1 (a) は GCB を模式的に表したものである. 高ガス 圧の $\mathrm{SF}_{6}$ ガスが充填された圧力タンク内に高電圧の電流端 子が貫通端子（ブッシング）を通して導入され, 中央に接点 が配置される．ここで接点を開くと, 接点間にアークが発生 するが, $\mathrm{SF}_{6}$ ガスの吹き付けにより消弧され電流が遮断され る.ここでは, タンクと高電圧部の絶縁も $\mathrm{SF}_{6}$ ガスで保た れる。

一方，Fig. 1(b)はVCBを模式的に表したもので，タン ク内に接点を囲む真空容器があり, 封じ切りで $10^{-3} \sim 10^{-6}$ $\mathrm{Pa}$ 程度の高真空に保たれる. 以降，この接点を持つ真空容 器部をVCB と区別して Vacuum Interrupter (VI) と呼ぶ. ここで接点を開くと接点間に真空アークが発生するが，真空 の拡散作用などにより強力に消弧され, 電流が遮断される. ここでは, タンクと高電圧部の絶縁は $\mathrm{SF}_{6}$ ガスなどの絶縁 ガスで保たれているが, 絶縁ガスには消弧能力が必要ないの で, 空気などの代替絶縁ガスに置き換えることが可能であ 


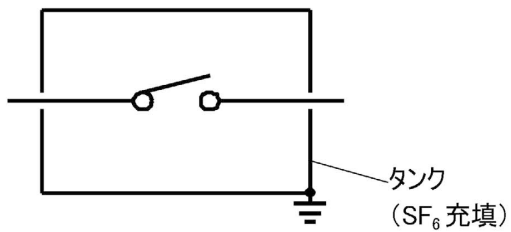

(a) GCB

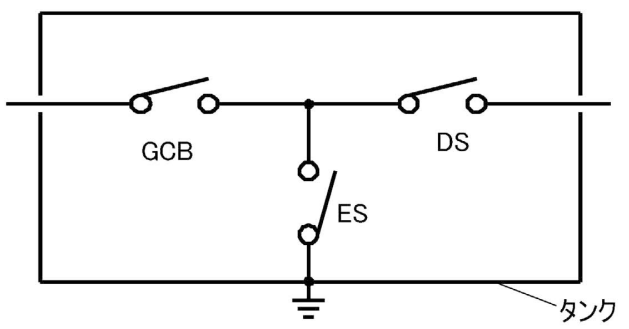

(c) GCB 適用 GIS

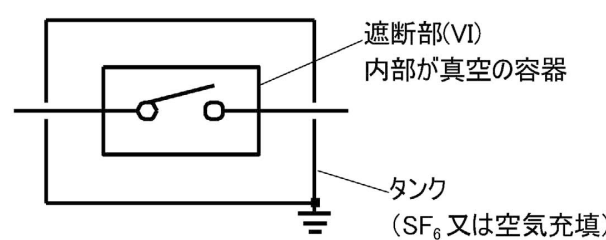

(b) VCB

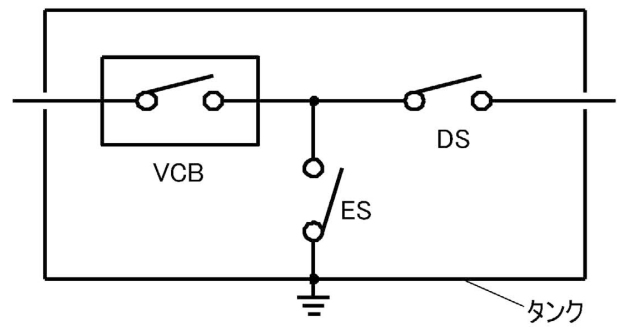

(d) VCB 適用 GIS

$\left(\mathrm{SF}_{6}\right.$ 又は空気充填)

Fig. 1 Configurations of GCB, VCB and GIS.

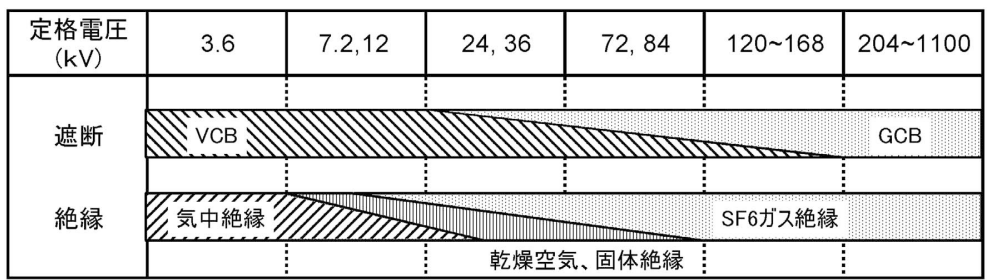

Fig. 2 Rated voltage ranges in application of GCB and VCB for circuit breakers and insulation systems.

る.ここに，脱 $\mathrm{SF}_{6}$ ガス機器を実現できる可能性がある.

上記は単体の遮断器について述べたが， $\mathrm{SF}_{6}$ ガスの使用量 が多いのは, 遮断器に加えて, 断路器 (DS), 接地開閉器 (ES) などを一括してタンク内に収めた複合機器である GIS である. GIS にも遮断部に GCB を適用したもの (Fig. 1(c)) と VCBを適用したもの（Fig. 1(d)）がある. DS E ES は 遮断器が電流を切った後で, 主に回路の切り替えに使われる ため, 大きな電流を遮断する責務はない，そのため接点の開 く速度は遅く, また, $\mathrm{SF}_{6}$ ガスや真空中でなくとも開閉が可 能である.すなわち GIS においても遮断部にVCBを適用し ていれば，脱 $\mathrm{SF}_{6}$ ガス機器を実現できる可能性がある。

Fig. 2 に遮断器, 開閉装置について, 電圧階級でみた $\mathrm{GCB}$ と VCBの適用範囲，および絶縁方式の適用範囲を示 す.

遮断器について見ると，高電圧では GCB が主流である. $\mathrm{GCB}$ は，熱パッファ方式と呼ばれる $\mathrm{SF}_{6}$ ガスの吹きつけに より強力にアークを消弧することができ, 遮断電流 $63 \mathrm{kA}$, 定格電圧 $1100 \mathrm{kV}$ のもまで開発されている．一方，VCB は電極を開閉する操作力が小さくコンパクトな遮断器を作る ことができること，また多数回の遮断が可能なことなどの特 徵から主に $84 \mathrm{kV}$ 以下の遮断器に適用されている. それ以上 の電圧では，極間の絶縁性能を確保するのが難しく高電圧化 が一つの課題であった．近年，電極材料や，適用技術が進ん だこともあり高電圧 VCB の適用が増えつつある.

一方, 絶縁方式について見ると, 特に $120 \mathrm{kV}$ 以上の高電 圧では $\mathrm{SF}_{6}$ ガスが中心である. $84 \mathrm{kV}$ 以下の開閉器につい
てみると, 遮断部に $\mathrm{VCB}$, 絶縁に $\mathrm{SF}_{6}$ ガスを利用して縮小 化したキュービクル形開閉装置 (C-GIS) が主流であったが， これらの機器をべースに $\mathrm{SF}_{6}$ ガス絶縁の代わりに乾燥空気 絶縁や固体絶縁を適用し, 完全に $\mathrm{SF}_{6}$ ガスを使用しない機 器の開発が進んでいる.

脱 $\mathrm{SF}_{6}$ ガス化が先行している中電圧クラスの機器は, 1 台 当たりの $\mathrm{SF}_{6}$ ガス使用量は少ないものの設置台数が多いた め，全体の $\mathrm{SF}_{6}$ ガス使用量削減に少なからず貢献できる. また, $\mathrm{SF}_{6}$ ガスの回収や廃棄 ・ リサイクル処理の作業が不要 になるためトータルライフサイクルコストの低減にも寄与す ることになる。

以降の章では, 近年の動向のうち, $\mathrm{VCB}$ の高電圧化と脱 $\mathrm{SF}_{6}$ 絶縁方式について述べる.

\section{3. 真空遮断器の高電圧 · 大容量化}

VCB は1960年代から普及が始まったが，当初から高電圧 化の試みがなされ，70年代には $84 \mathrm{kV} 1$ 点切り, $168 \mathrm{kV} 2$ 点切の製品化が行われた ${ }^{1)}$. これらの遮断器は画期的なもの であったが，電極としてはスパイラル電極であり，VI も複 雑なシールド構造をもった大型のものであった。 その後, 1980年代の $\mathrm{Cu}-\mathrm{Cr}$ 系電極材の登場, 遮断能力に優れた縦磁 界電極構造の採用, 90 年代後半の $72 / 84 \mathrm{kV}$ セラミック VI の開発などの進展があった，そして，21世紀に入り $145 \mathrm{kV}$ 1 点切 VCB (Fig. 3, Fig. 4) の試作を経て $120 \mathrm{kV} / 31.5 \mathrm{kA}$ 1 点切り, $168 \mathrm{kV} / 40 \mathrm{kA} 2$ 点切りの $\mathrm{VCB}$ が開発された ${ }^{2)}$. 以下，これらの開発を支えた技術について概説する. 


\section{(1) 高電圧化}

耐電圧性能の向上には電極材料に高 $\mathrm{Cr}$ 含有量の $\mathrm{Cu}-\mathrm{Cr}$ 合 金を採用することにより通電性能と耐電圧性能の向上を両立 させることが出来た. また, 真空中の絶縁破壊特性として放 電を繰り返すことで電極表面の酸化物や微小な突起などの弱 点が除去されて破壊電圧が上昇していく，コンディショニン グ効果があることが知られている. この特性を有効に活用 し, かつ電界解析による形状の最適化を組み合わせることで 従来以上の耐電圧性能の向上を達成した.

\section{(2) 大容量化}

遮断容量（遮断電流 $\times$ 電圧）の増加は縦磁界電極の発展に よりもたらされた. 従来のスパイラル電極に比べて電極面の 局部的な溶融が少なく, 高電圧 - 大容量領域の適用に有利で ある. 電流の通電経路をコイル状にし, 遮断しようとする電 流自身が電極間に磁界を発生させることでアークを安定化さ せている，そのため，その構造を最適化するため磁界解析 · 磁界測定と並行してアーク観測を行っている（Fig. 5).

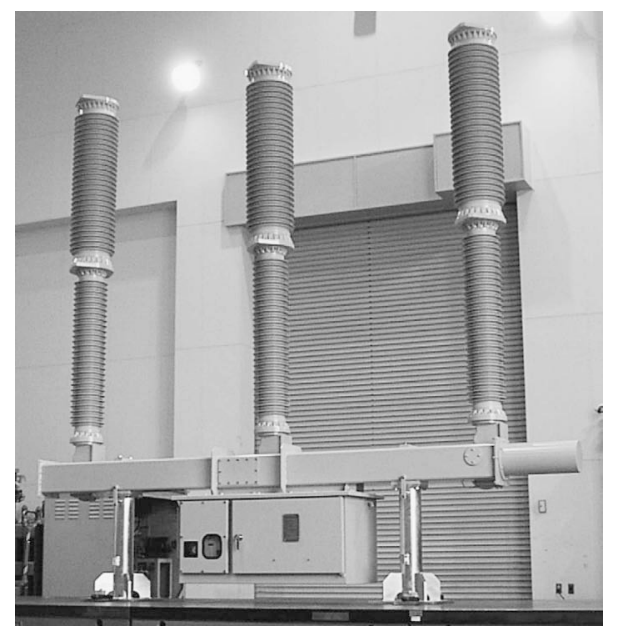

Fig. $3145 \mathrm{kV} / 40 \mathrm{kA}$ single break VCB.

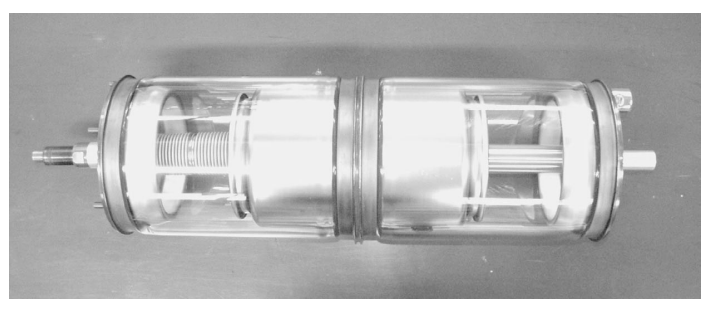

Fig. 4 VI for $145 \mathrm{kV}$ VCB.

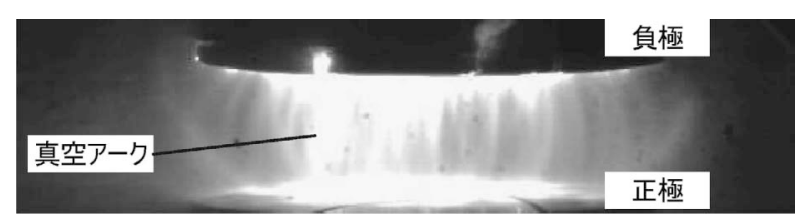

Fig. 5 Vacuum arc observation by high-speed VTR during interrupting $40 \mathrm{kA}$ using axial magnetic field type electrode system.

\section{4. 脱 $\mathrm{SF}_{6}$ ガス絶縁方式}

(1) 乾燥空気絶縁

$\mathrm{VCB}$ は遮断に $\mathrm{SF}_{6}$ ガスを使わないため, 絶縁に乾燥空気 を用いれば完全に $\mathrm{SF}_{6}$ ガスフリーの遮断器となる. 一般に乾 燥空気は $\mathrm{SF}_{6}$ ガスと同じガス圧力の場合, $1 / 3$ 程度の絶縁性 能しかない. そのため, 従来機種と同じ機器の寸法とするた めには, ガス圧力を上げる方法がとられる. それでも絶縁性 能が不足する場合には導体表面に被覆やコーティングをする などして, 固体の高い絶縁性能を組み合わせた複合絶縁技術 が用いられる。

\section{(2) 高耐圧力 VI}

高ガス圧力中にVIを配置した場合, 従来の内圧方式 (Fig. 6(a)）では真空との差圧により過大な応力が VI 及び ベローズに加わる. 特に, ベローズでは圧力差による座屈の 防止が課題となる. 一方べローズの外側から圧力の加わる外 圧方式 (Fig. 6(b)) は座屈しにくいのが特徵であり, 高耐 圧力化に適している. 検証試験では差圧 6 気圧での連続動 作試験を行い, 1 万回の開閉操作を保証する寿命を確保して いる.この高耐圧力 VI を適用した $72 / 84 \mathrm{kVSF}_{6}$ ガスレス タンク形 VCB が開発されている $(\text { Fig. 7, Fig. 8 })^{2)}$ 。さら にこの技術の適用を拡大し, $72 \mathrm{kV}$ 乾燥空気絶縁 GIS の遮 断部としても利用されている3). もうひとつの方法として, 2 重圧力式がある (Fig. 6 (c) ). VIベローズ内部を一つの ガス区分とし，ブッシング先端で大気と通気させることによ りこの区分を大気圧としている.これにより, タンク内の他 のガス区分を $0.5 \mathrm{MPa}$ 程度の高圧力としながらも, ベロー ズ部分では VI 内外の圧力差が $0.1 \mathrm{MPa}$ とすることができる. 2 重圧方式は, VI 自閉力の低減による低操作力化, 一般的 な低圧力方式ベローズの採用などのメリットがあり，72/84 $\mathrm{kV}$ タンク形 VCB が開発されている4).

\section{(3) 低気圧乾燥空気絶縁}

キュービクル形開閉装置では低ガス圧で導体も不平等電界 の形状をもつため GIS 等と比較して絶縁設計の考え方が異

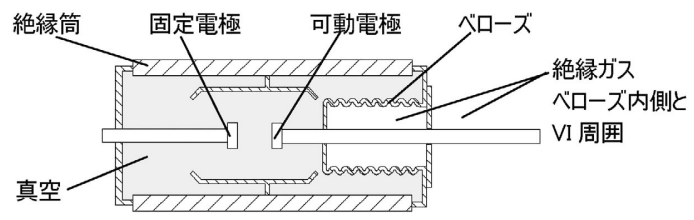

(a) 従来(内圧) 方式

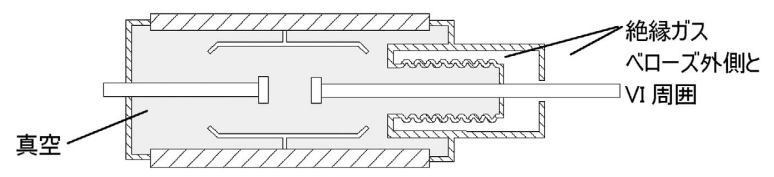

(b) 外圧方式

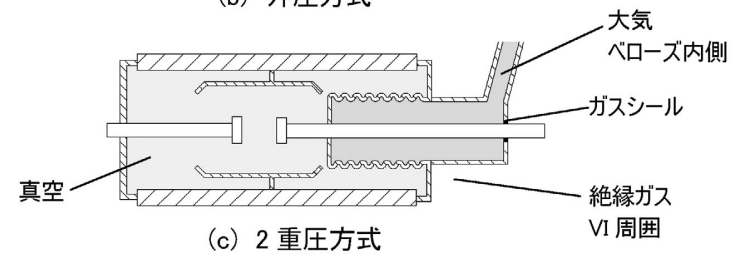

Fig. 6 Cross section views of high-pressure VI's. 


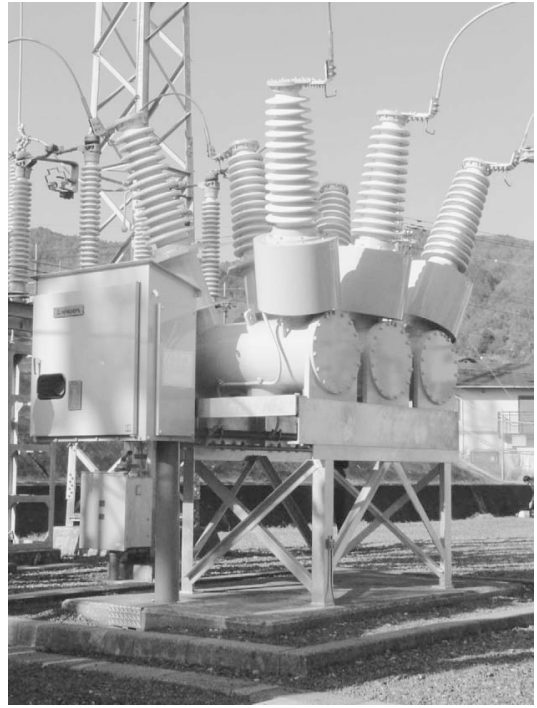

Fig. $7 \quad 72 / 84 \mathrm{kV}-31.5 \mathrm{kA}$ dry air insulated VCB.

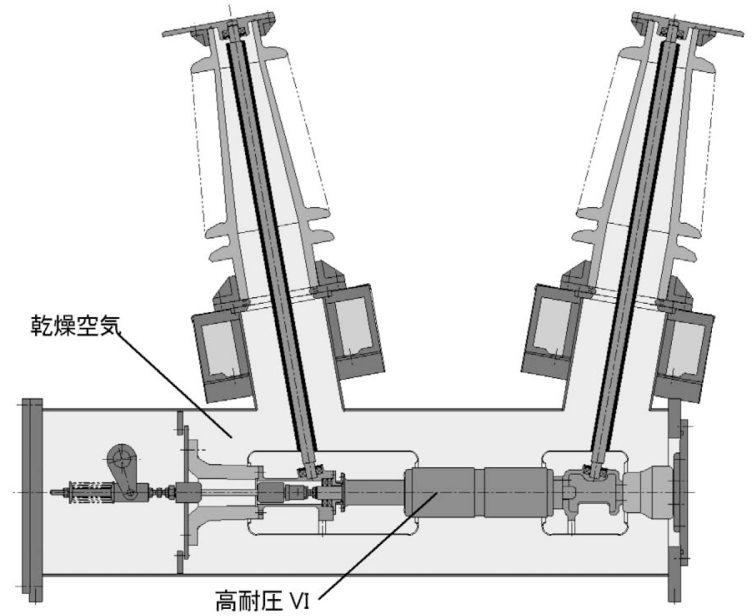

Fig. 8 Internal structure of $72 / 84 \mathrm{kV}$ dry air insulated VCB.

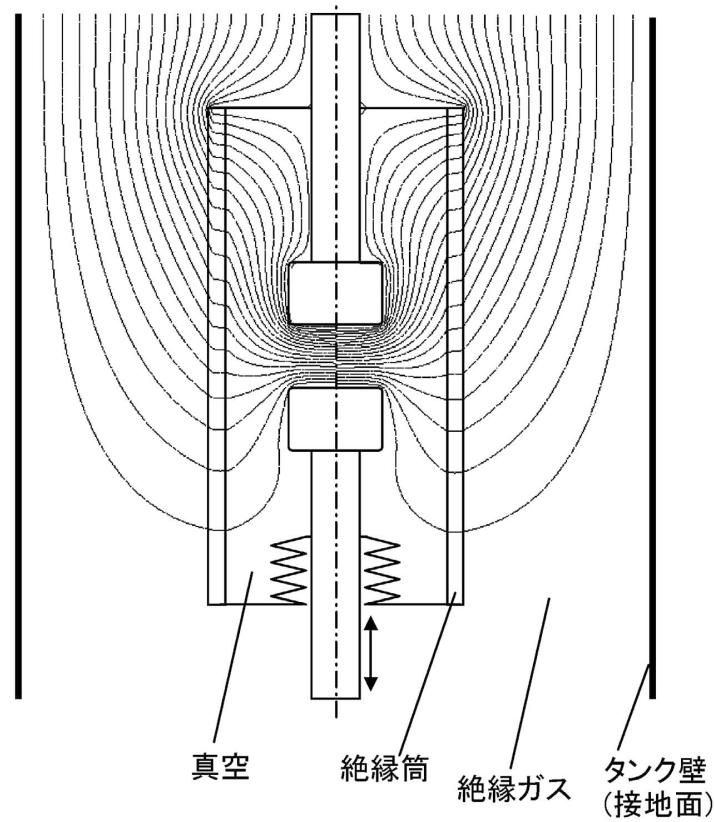

(a) ガス絶縁方式
なる. 大気圧から 2 気圧程度の領域ではギャップ長や電極 の形状によって大気圧の $\mathrm{SF}_{6}$ ガスと 2 気圧の空気の絶縁破 壊電圧が同程度になる場合がある。この特性を利用し定格電 圧 $24 \mathrm{kV}$ のキュービクル形乾燥空気絶縁開閉装置が開発され ている $(\text { Fig. 9 9 })^{5)}$. 0.1 MPa 程度の乾燥空気を絶縁ガスと して用いているため, VI は高耐圧力仕様ではなく通常設計 のVIが利用でき, 低コスト化を実現している.さらに被覆 やバリアを適用することで高耐電圧化を図り, 低ガス圧の乾

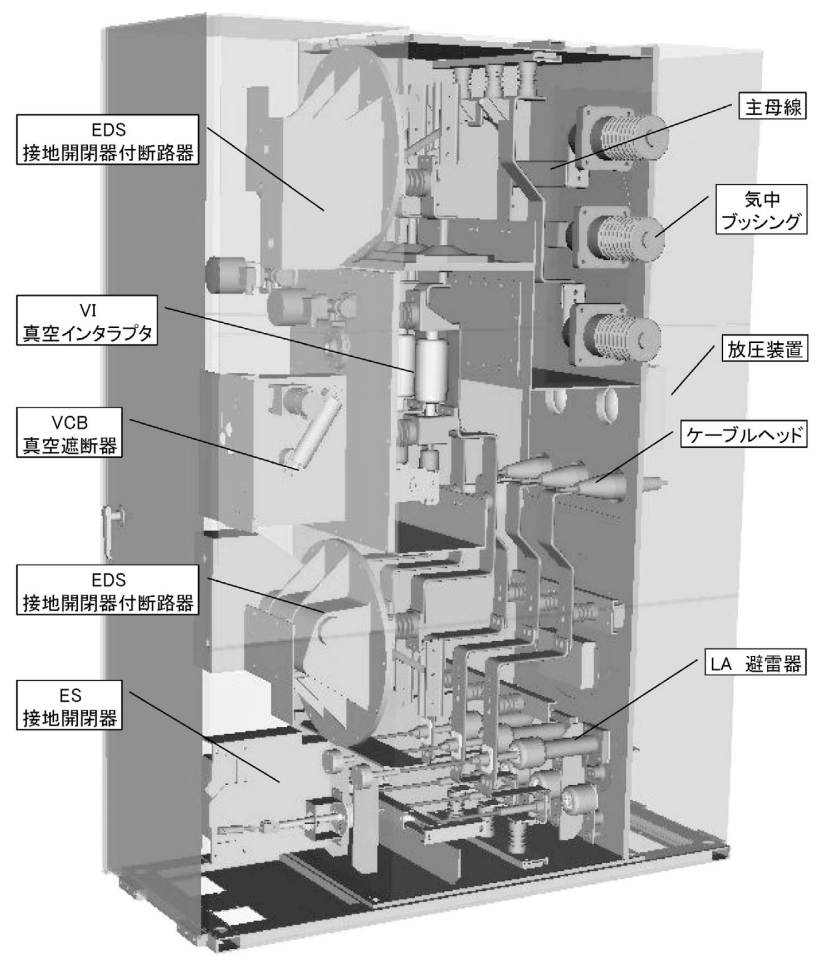

Fig. 9 Internal structure of $24 \mathrm{kV}$ dry air insulated Switchgear.

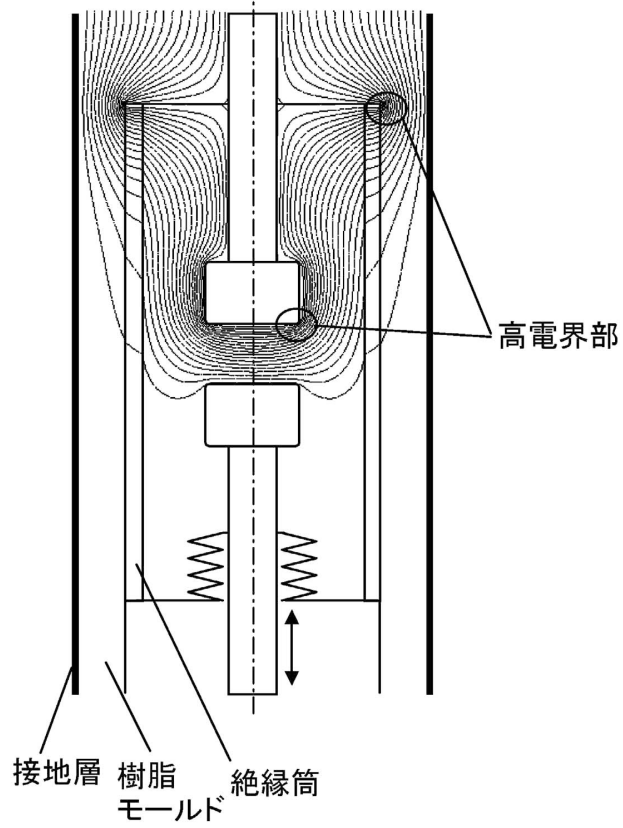

(b) 固体絶縁方式

Fig. 10 Typical structures of conventional gas insulated VCB and solid insulated VCB. 
燥空気で $72 \mathrm{kV}$ までの C-GIS が開発されている ${ }^{6)}$.

\section{（4）固体絶縁}

遮断部は VI を用い周囲をエポキシなどの固体でモールド し，さらにモールドの周囲に接地層を形成する固体絶縁方式 も脱 $\mathrm{SF}_{6}$ 機器として有望である. Fig. 10に一般的なガス絶 縁方式と固体絶縁方式の配置を比較し, 電界解析によりもと めた等電位線図を重ねて表示した。 固体絶縁方式は, 固体の 高い絶縁性能により接地面までの絶縁距離を小さくすること ができ, 機器の縮小化という意味では理想的な絶縁方式であ る. 一方, 技術的なハードルは高く, いくつかの課題があ る. 例えば，モールドの樹脂と金属やセラミックとの線膨張 率の違いから, 繰り返しの温度変化があると界面や応力集中 部でクラックが入ることが予想される。そこで，あらかじめ 応力計算などにより応力が集中しない構造になるように検討 する必要がある。またVI と接地面が近づくため, VI 内部 やモールド内部の電界が高くなる傾向にあり，VIの場合は 遮断性能の低下，モールド内部は長期的な絶縁劣化に注意が 必要である.また, VIの可動電極などの可動部はモールド で固めることはできないので，高電圧化に対してネックにな る. 以上の様な課題があるものの, 定格電圧 $36 \mathrm{kV}$ までの固 体絶縁 C-GIS が開発されている7).

\section{5.あとがき}

$\mathrm{VCB}$ は消弧媒体として $\mathrm{SF}_{6}$ ガスを使わない高電圧 · 大容 量遮断器としての期待が高まっている. 今後, より高電圧・ 大容量化へと進むためには，GCB と比較した場合のコスト 面や，真空中での冷却効率の悪さによる通電容量などの課題 を解決する必要がある，また，環境低負荷形の機器としての $\mathrm{VCB}$ は， $\mathrm{SF}_{6}$ 代替ガスとして乾燥空気を絶縁に用いたもの が主流になり，72 kV 以下ではその適用がさらに拡大してい くものと思われる。

\section{〔文献〕}

1) T. Takashima, T. Kikuta, R. Nakanishi and A. Hirakawa: Meiden Review, No. 2, (1979) 9.

2) Y. Matsui, K. Nagatake, M. Takeshita, K. Katsumata, A. Sano, H. Ichikawa, H. Saitohu and M. Sakaki: Proc. 22 ${ }^{\text {nd }}$. Int. Symp. on Discharges and Electrical Insulation in Vacuum, Matsue, Japan, 2006, 1 (2006) 253.

3) T. Rokunohe, Y. Yagihashi, K. Aoyagi, T. Oomori and F. Endo: IEEE Transactions on Power Delivery, 22 (2007) 1869.

4) H. Saito, K. Nagatake, H. Komatsu, Y. Takeshita, Y. Matsui, K. Katsumata and M. Sakaki: IEEJ Trans. PE, 129 (2009) 353.

5) N. Tamaki, K. Naito and T. Chou: AE Power Systems Review, 1 (2008) 38.

6) T. Yoshida, H. Koga, T. Harada, S. Miki, M. Arioka, S. Sato, S. Yoshida, N. Inoue, A. Maruyama and T. Takeuchi: IEEJ Trans. PE, 128 (2008) 1439.

7) S. Fujii, O. Sakaguchi and J. Sato: Toshiba Review, 59 (2004) 56. 